\title{
Effective Guidance and Counselling Programmes in Secondary Schools: Issues and Roles in Students' Career Decision Making
}

\author{
Tina Nweze (P.hD) ${ }^{1}$ and Ugochukwu Chinonso Okolie ${ }^{2}$ \\ ${ }^{I}$ Department of Education Foundation, Ebonyi State University, Abakaliki \\ ${ }^{2}$ Department of Technology and Vocational Education, Ebonyi State University, Abakaliki
}

\begin{abstract}
Career decision making is a skill that counsellors can use to assist students learn, it involves conscious, systematic process which students can learn and perform better practice. This study therefore, was designed to examine guidance and counselling programmes in secondary schools: it also determined issues and roles of the programme in students' career decision making. The study adopted an ex-post facto descriptive survey design and covered senior school students in ten selected secondary schools in Ebonyi State, Nigeria. Simple random sampling techniques were employed in selecting the sample for the study and utilized 300 respondents; 30 head teachers and 27 students from each of the ten selected schools totalling 270 students. Two different questionnaires were designed for the study data collection which was Senior Secondary School Students Questionnaire (SSSSQ) and Secondary School Teacher Counsellors Questionnaire (SSTCQ). 270 copies of questionnaires were administered to students through the help of research assistants and 180 copies were filled correctly and returned giving a return rate of 90 percent. Also 30 copies of questionnaires were administered to selected teachers and all were filled and returned. However, construct and face validity was established as experts in guidance and counselling validated the instruments. Reliability coefficient of 0.65 was established for the students' instruments (SSSSQ) while the reliability coefficient of 0.67 for the teacher's instrument (SSTCQ). Findings among others revealed that $77.22 \%$ of the population proved that there is little or no form of counselling services to assist students in career decision-making in their respective schools while $73.33 \%$ of the study population felt that counselling resources for teacher counsellors are unavailable and insufficient in their respective schools. Conclusion and recommendations were drawn from the findings made.
\end{abstract}

Keywords: Career decision making, Guidance and Counselling, Counselling Services

\section{Introduction}

The most dominant single influence on the cause of one's life is the person's work. This also affects one's family structure, social and intellectual activities, economic position, personality and happiness. One's occupational/career choice is mostly influenced by parents, friends, relatives, teachers, printed information, scholarship awards and pressure groups etc. Career decision making, is a process of finding the best possible match of a person with a particular kind of work. Dada (2005) asserts that many youths do not know what to do when they plan to take decisions on occupational choices; these eventually lead many to take on wrong jobs. Also, many graduates presently do uninteresting jobs, which they got into due to lack of career decision-making. Ike (1997) further opined that a lot of students do not know what to do with their lives and where they're going after school. Therefore, to assist such students develop their potentials, the school guidance and counselling programme must be effective to guide them regarding the requirement of specific occupations; the services of the guidance and counsellors are highly required as their efforts assist in placing talents where it is mostly needed.

The word 'career' mean job, occupation or vocation a person has, because their use overlap. Career is a series of jobs that a person has in a particular area of work, usually involving more responsibilities as time passes (Okonkwo, 2011). It is a work or profession, which occupies one's time from which the adjective occupational was coined. The specific and real meaning of career is the pattern of work and work related activities that develop through a lifetime. It also includes the job or series of jobs a person has until retirement.

Guidance and counselling on the other hand, is a helping career, which is a moulding, rebuilding and rehabilitating process. It is a self informative relationship, and it is both pre-emptive and restorative of maladaptive and self destructive tendencies. Guidance and counselling focuses on individual and its highly required in the schools, colleges, higher education institutions, hospitals, in courts, in the industries and companies; but for the purpose of this paper, the main focus is on guidance and counselling programmes in the secondary schools.

Formal guidance and counselling can be traced to America in the late 1890s and the early 1900s. Frank Parsons who has been called the father of vocational guidance was among the pioneers of the guidance and counselling movement. Through his efforts, guidance and counselling became an organized service and it gained recognition for its important contribution in society. Parsons established the first career institution in the 
U.S.A, and set the pace for the development of psychological testing. Gradually the guidance and counselling movement developed into an organized service, which has continued to make a significant contribution to the development of society (Makinde, 1984; Nyamwange, Nyakan and Ondima, 2012).

The word, guidance and counselling have been used either individually or synonymously by various authors; as a result, many texts interchangeably use the term guidance for counselling and vice versa. The general consensus among specialists is that guidance is a family name for all the helping services within the general educational and community systems. Ipaye (1983) stated that guidance is a general label, an umbrella term that covers all the means where an institution identifies and responds to the individual needs for pupils, help the pupil to develop his/her maximum potential. Counselling also, is a subset of the general term called guidance.

Guidance and counselling in secondary schools is riddled with a number of problems which are attitudinal, structural, human and cultural. These include malfunction to engage in careful analysis of organizational problems that guidance and counselling was intended to resolve. There have been lack of trained school counsellors in secondary schools and colleges, and lack of sufficient time, facilities and orientation materials for use by counsellors. It was against this background that this study was designed to undertake an analysis of effective guidance and counselling programmes in secondary schools to examine its issues and roles in students' career decision making.

\section{Statement of the Problem}

The National Policy on Education (2004) states that education is an instrument for effective national development. This means that a student is expected to acquire skills and experiences required to be fit in the world of work after graduation. It is through the graduate's occupation that she/he is expected to serve the country, contribute and at the same time benefit from the economic growth and national development. But if the student is not properly guided on career decision-making by a professional guidance and counsellor, it would not be possible for such student to contribute to economic / national development after graduation. This therefore has defeated the objectives of education as stated in the national policy on Education of the Federal republic of Nigeria.

Guidance and counselling programmes in Nigerian education system has not been given the attention it deserves. And until the attention is given to this form of education programme, majority of secondary school students will continue to find it difficult in career decision making. Okolie (2014) asserts that many college students lack ideas on which course to study in the higher education institution after leaving the schools. The reason is because; they lack services of professional guidance and counsellor who'll assist them in career decision-making. It has been observed that many students who perform well in mathematics and science technology related subjects in secondary schools end up studying arts or social science related courses in the University instead of studying science, technology or engineering related courses to pursue their careers the relevant fields; this is mostly seen in Nigerian education institutions. After been admitted into the University, such students find it difficult copping with other students who choose the right courses leading to their chosen career path (Okolie et al, 2014).

\section{Purpose of the Study}

This study assessed effective guidance and counselling programmes in secondary schools: issues and roles in students' career decision making. To attain this objective, the researcher examined the availability of the essential resources and the guidance and counselling teachers' attitudinal and professional preparedness to provide the guidance and counselling services. The researcher was also concerned about establishing the attitude of secondary school students and stakeholders towards guidance and counselling for effective career decisionmaking and how this impact on the quality of guidance and counselling services provided to Nigerian secondary school students.

\section{Significance of the Study}

Guidance and counselling is a procedure of assisting persons to know themselves by discovering their desires, interests and capabilities in a bid to prepare their own goals and create strategies for realizing those goals. An appraisal of issues and roles of guidance and counselling in students' career decision making is of paramount importance, hence this study. The results from the study will assist shed light on the challenges facing providers of guidance and counselling services in secondary schools in Nigeria. In addition, the study will offer fundamental information to education planners which can be used to raise policy on how to reinforce guidance and counselling programmes in secondary schools in Nigeria and beyond. 


\section{Methodology}

The study adopted an ex-post facto descriptive survey design. The scope of the study covered senior secondary school students in selected secondary schools in Ebonyi State, Nigeria. Simple random sampling techniques were employed in selecting the sample for the study and utilized 300 respondents; 30 head teachers and 27 students from each of the ten selected schools totalling 270 students. Two different questionnaires were designed for the study data collection. The questionnaire was Senior Secondary School Students Questionnaire (SSSSQ) and Secondary School Teacher Counsellors Questionnaire (SSTCQ). The SSSSQ consisted of 10 items sourcing information from respondents about their approach towards guidance and counselling and information about assessment of sufficiency of counselling services in their schools. SSTCQ also consist of 10 items as well as sourcing information from respondents about availability of counselling resources for teacher counsellors and the roles of guidance and counselling programmes in assisting students through career decisionmaking. The respondents in each case were requested to indicate the extent to which they agreed or disagreed to each item. 270 copies of questionnaires were administered to the students through the help of research assistants and 180 copies were filled correctly and returned giving a return rate of $90 \%$. Also 30 copies of questionnaires were administered to selected teachers and all were filled and returned. However, construct and face validity was established as experts in guidance and counselling validated the instruments. Reliability coefficient of 0.65 was established for the students' instruments (SSSSQ) while the reliability coefficient of 0.67 for the teacher's instrument (SSTCQ).

\section{Data Analysis}

In the analysis of data, both descriptive and inferential statistics were used to analyze the data. Some of the data obtained was ostensible and the chi-square test was used for analysis, which was performed at a significance level of $5 \%$.

\section{Results}

Table 1 Responses from Respondents on Students Approach to Guidance and Counselling Programmes

\begin{tabular}{lcc}
\hline Responses & Frequency & Percentage (\%) \\
\hline Strongly Agree & 29 & 16.11 \\
Agree & 32 & 17.78 \\
Disagree & 47 & 26.11 \\
Strongly Disagree & 72 & 40.00 \\
\hline Total & $\mathbf{1 8 0}$ & $\mathbf{1 0 0}$ \\
\hline
\end{tabular}

Table 1 show that 61 respondents representing $33.89 \%$ of the study population agreed that they have very good approach or attitudes to guidance and counselling programmes in their schools while 118 respondents representing $66.11 \%$ of the total study population agreed that they have very poor approach to guidance and counselling programmes in school. This is line with the findings of Kombo and Tromp (2006) that students have somewhat negative attitude towards guidance and counselling services. The result also concur with Nyamwange, Nyakan and Ondima, (2012) which indicated that $56.2 \%$ of the total number of students that formed the population of their study did not consider counselling necessary in their schools while only $43.8 \%$ felt it is necessary. They observed that only $38 \%$ of the students used for their study considered guidance and counselling vital in boosting their self understanding. This sort of students' attitudes must be changed by school administrators if the general educational goals and objectives of the National Policy on Education (2004) would be met. Study conducted by Muango and Joel (2012) revealed that students who showed negative approval of the career counselling services were perhaps influenced by the fact that they knew what career path to pursue and thus found it unnecessary to seek the services. It could have been precipitated by lack of knowledge on the existence of career counselling services in the school. The findings further concur with Locke \& Latham (1990), who were of the view that programmes offered by guidance and counselling departments assist students to overcome academic and career challenges.

Guidance and counselling programme must have four components: Personal/Social Guidance, Educational Guidance, Careers Guidance, and a strong orientation programme for new students and for students proceeding to higher education levels within the school (Mapfumo, 2001). Whiston (2003) asserts that the bases of guidance and counselling assessment is to serve as a basis for information on personal counselling, educational counselling, career development and placement to further education and work, in transitional stages of instruction. According to Mutie \& Ndambuki (2003), a student faces many difficult situations in life today; he/she has to make intelligent choices in curricular and other activities, acquire basic study skills for optimum achievement, and adjust to his/her peers, teachers and parents. The student also has to live and share facilities in the institutions, hostels, dormitories, with individuals from different economic and social backgrounds. The personal and social development of young students' has become the responsibility of learning institutions to the 
extent that today such institutions require a more formal structure and explicit definition of responsibilities (Owino, 2005). Therefore, it is the duty of the schools to make students have very good approach / attitudes towards guidance and counselling as this will enable them appreciate the directives of the guidance and counselling professional and at the same time assist them in career decision making.

Table 2 Responses from Respondents on Students' evaluation of counselling services in schools

\begin{tabular}{lcc}
\hline Responses & Frequency & Percentage (\%) \\
\hline & & \\
Strongly Agree & 15 & 8.33 \\
Agree & 26 & 14.44 \\
Disagree & 58 & 32.22 \\
Strongly Disagree & 81 & 45.00 \\
\hline Total & $\mathbf{1 8 0}$ & $\mathbf{1 0 0}$ \\
\hline
\end{tabular}

Table 2 revealed that students felt that there are little or no counselling services in schools to assist them in career decision making. Results showed that only 41 respondents representing $22.77 \%$ of the study population agreed that there are available counselling services for them in their schools. These findings coincide with Idowu (2004) that school teachers who also act as counsellors often lack time to provide students guidance and counselling services; also, majority of the teachers who work as school counsellors are overloaded with duties and often suffer from professional burnout. Meanwhile, 139 respondents representing $77.22 \%$ of the population proved that there is no form of counselling services to assist them in career decision-making in their respective schools.

In a study conducted by Muango and Joel (2012), it was revealed that $56 \%$ of the respondents rated career counselling services as being favourable, $30.4 \%$ as average and $14.6 \%$ rated unfavourable. The positive view of students towards career counselling services offered in schools suggest that they benefit from such services, while the students with negative views towards career counselling may have been influenced by pressure groups, parents and family members etc. It was also observed that school management usually appoint a teacher to act as school counsellor so as to provide students with guidance and counselling services but in most cases, such teacher spends the whole three school terms without counselling a single student concerning his/her academic performance, career choice, self-understanding etc.

All teachers are expected to play a caring role in their daily dealings with their students. Guidance teachers who are full-time teachers with extra guidance duties are involved in the development and management of the school's guidance program that aims to support the "whole-person" development of all students (Yuen, 2002). Full-time guidance professionals and teachers should work together to conduct guidance activities such as implementing a guidance curriculum (e.g., personal growth education), providing responsive service (e.g., individual counseling and group guidance), delivering support services (e.g., parents' education and teacher consultation), individual planning (e.g., career and education guidance workshops), and organization and management (e.g., program development and evaluation). Within this range of activities, individual student planning is perceived by teachers as being implemented now to a lesser extent than other guidance activities in schools (Yuen, 2006).

Attention needs to be prearranged to developing a school counselling curriculum as part of the training should focus on promotion of pliability among students through improving academic performance, engaging in relational networking with family and friends, career decision-making and vigorous participation in community service. More effort is necessary to elucidate the functions and purposes of school counselling. This attempt should be focused on arrangement that includes developmental, preventive, and corrective functions.

Table 3 Availability of counselling resources for teacher counsellors

\begin{tabular}{ccc}
\hline Counselling resources & Frequency & Percentage (\%) \\
\hline Available/ Sufficient & 08 & 26.67 \\
Unavailable / Insufficient & 22 & 73.33 \\
\hline Total & $\mathbf{3 0}$ & $\mathbf{1 0 0}$ \\
\hline
\end{tabular}

Table 3 shows that 8 respondents representing $26.67 \%$ of the secondary schools teacher study population felt that the available counselling resources for teacher counsellors were adequate and sufficient to meet their counselling requirements in schools. However, 22 respondents representing $73.33 \%$ felt that counselling resources for teacher counsellors are unavailable and insufficient in their respective schools. This is in line with the findings of Nyamwange, Nyakan and Ondima, (2012) that $57.2 \%$ and $76.2 \%$ respectively representing the total population of their study agreed that guidance and counselling offices and career resource centres are insufficient. In many secondary schools used for the study, guidance and counselling offices lack books, journals and other counselling materials to aid the teacher counsellors; others do not have counselling 
resources at all and this affects the students in career decision making. Idowu (2004) asserts that clearly, there has been consensus that there is inadequacy in the role of the school in preparing the Nigerian child for the aspired future. Idowu's statement could be seen in the manner and ways school management handles guidance and counselling programmes in Nigeria.

Table 4Head Teachers Responses on the Roles of Guidance and Counselling Programmes in Secondary Schools

\begin{tabular}{lcccccc}
\hline \multicolumn{1}{c}{ Items } & Agree & $\mathbf{\%}$ & Disagree & $\mathbf{\%}$ & X & total \% \\
\hline Personal Growth & 19 & 63.33 & 11 & 36.67 & 30 & 100 \\
Self Understanding & 17 & 56.67 & 13 & 43.33 & 30 & 100 \\
Academic performance & 07 & 23.33 & 23 & 76.67 & 30 & 100 \\
Career Decision-making & 25 & 83.33 & 05 & 16.67 & 30 & 100 \\
\hline
\end{tabular}

Table 4 presented the teachers responses on the roles of guidance and counselling programmes in secondary schools. 19 respondents representing $63.33 \%$ agreed that one of the major roles of the guidance and counselling programmes in secondary schools is personal growth. Students who have access to counselling services have human dignity, worth and academic growth. According to Idowu (2004), counselling services enable individuals to attain maximum satisfaction, to realize their potentials and to be aware of self and no one who has gone through counselling should feel put down.

Also, the study revealed that self understanding is another role of guidance and counselling; 17 respondents, representing $56.67 \%$ agreed to this. Idowu (2004) asserts that guidance and counselling services is an important aspect of the school programme, hence it aims at assisting the students to effect changes in their behaviour processes thereby acquiring ability to enhance their functioning, live a more productive and selfsatisfying life. The activities in counselling service include the use of variety of approaches in one-on-one or group interaction to aid students implore and understand better about their needs, feelings, values, attitudes, strengths and weaknesses, self concept, how they relate to others and the environment in order to become self directing individuals.

7 respondents representing $23.33 \%$ of the study population felt that guidance and counselling programme in secondary schools enhances academic performance while 23 respondents representing $76.67 \%$ of the study size felt that guidance and counselling programmes in schools do not enhance students' academic performances. In a similar study conducted by Nyamwange, Nyakan and Ondima, (2012), it was showed that $24 \%$ of the study respondents agreed that guidance and counseling plays positive roles in improving students' academic performance while $76 \%$ of the study population felt that it does not have many roles in enhancing student's academic performances.

However, 25 respondents representing $83.33 \%$ of the total study population agreed that guidance and counselling play vital roles in assisting students through career decision-making, while 5 respondents representing $16.67 \%$ felt that guidance and counselling does not really play a role in students' career decisionmaking. Nevertheless, one must note that how students of today meet problems of tomorrow will depend on the amount of success they would achieve in planning for that tomorrow and planning for tomorrow in this case is primarily the responsibility of the students' parents, teachers and school counsellors. Kerr (2003) asserts that the broad range of opportunities available to multi- potential youths tend to increase the complexity of decision making and goal setting. Idowu (2004) opined that the rapid changes going on in the adolescent's private world as well as in the world of work around him, call for careful planning and guidance so that the chances of making errors will be reduced to the barest minimum. Also, there is apparent lack of knowledge about work options and career alternatives. New careers are being added every now and then as a result of technological breakthroughs and new inventions.

\section{Conclusion}

This study has established that guidance and counselling is a procedure of designed intervention within a school system by which the total development of students are enthused in areas relating to their personal, social, career, emotional and academic concerns. School guidance and counselling programmes have therefore been introduced to assist students overcome the number of challenges they experience at home and at school. But because of many pressures imposed on the family, parents tend to have little time with their children to give them the necessary guidance. The parents expect the school to provide solutions to the indiscipline in secondary schools caused by their children and as well assist them to make career choices. The study has also identifies inadequate guidance and counselling resources, unenthusiastic attitude towards guidance and counselling from students and head teachers, lack of adequate support from stakeholders and education policy makers to guidance and counselling programmes, insufficient training of teacher counsellors on guidance and counselling and overburdening of teacher counsellors with heavy teaching work weight have sufficiently influenced the excellence of guidance and counselling services in secondary schools in Nigeria. This study still maintains that for Nigeria to meet the goals and objectives of the general education, which is to train people who'll contribute 
to economic growth and national development, guidance and counselling must be given the attention it deserves in secondary schools.

\section{Recommendations}

In order for Nigeria to benefit from guidance and counselling programmes and enjoy the roles for which it was anticipated in secondary schools, it requires concentrated hard work from all the school managements and policy makers in the education process. Based on this, the following recommendations have been offered;

- Nigerian secondary school managements should provide essential resources for guidance and counselling. These resources include counselling office equipped with orientation materials as well as adequate career resource materials.

- School guidance workers should be encourage to frequently interact with the school students so that they may understand the nature and purpose of guidance and their roles in the entire school programme.

- The secondary school counselling teacher should endeavour to assemble other teachers to assist in creating wakefulness and advising students on the significance of counselling services.

- Teacher counsellors are supposed to attend conferences and seminars to equip themselves with latest literatures, theories and techniques of counselling in schools. School managements should be responsible the financial implication of such conferences and workshops.

- School managements and education policy makers are expected to raise the guidance and counselling awareness in Nigeria through the media and information sharing. This will reduce the negative attitudes and approaches secondary students and some head teachers have for such programme.

\section{References}

[1]. Dada, E. O. (2005). Utilization of product Evaluation for Curriculum issues and Development in Vocational Technical Education. $\begin{array}{lll}\text { Akaoka. Journal of } \quad \text { Vocational Education. } 4 & \text { (1) } 145-152\end{array}$

[2]. Federal Republic of Nigeria (2004). National Policy on Education (4 ed.) Lagos: NERDC Press.

[3]. Idowu, A. I. (2004). Guidance and Counselling in Education. Ilorin. Indemac publishers.

[4]. Ike, C. S. (1997). Psychometric and Ethical Considerations in Counselling. Enugu. Auto Century Publishing Ltd.

[5]. Ipaye, T. (1983). The Roles of the Home, the Community and the School in Guidance and Counselling. In A Uba (ed.). Introducti on to Counselling. Ile-Ife. University of Ife Press.

[6]. Kerr, B. A. (2003). Career Planning for Gifted and Talented Youth. Retrieved June, 132014 from career planning for gifted and talented youth.htm.

[7]. Kombo, K. D. \& Tromp, D. L. A (2006) Proposal and Thesis Writing: An Introduction. Nairobi: Paulines Publications Africa.

[8]. Locke, D. \& Latham, G. (1990). The Goal Setting Theory. London: Macmillan Publishers.

[9]. Makinde, O. (1984) Fundamentals of Guidance and Counselling. London: Macmillan Education Ltd.

[10]. Mapfumo, J. S. (2001). Guidance and Counselling in Education. Module PGDE 012. Harare: Zimbabwe Open University.

[11]. Muango, G. and Joel, O. J. P. (2012). An Evaluation of the Effectiveness of Guidance and Counselling Services in Public Universities in Kenya. Journal of Emerging Trends in Educational Research and Policy Studies. 3 (2). 151-154.

[12]. Mutie, E. K. and Ndambuki, P (1999). Guidance and Counselling for Schools and Colleges. Nairobi: Oxford University Press.

[13]. Nyamwange, Nyakan and Ondima, (2012). Assessment of Challenges facing Secondary School Guidance and Counselling Teachers in Nyamira District, Kenya. Journal of Education and Practice. 3(16).41- 47

[14]. Okolie U. C. (2014), Management of Woodwork Workshop in Tertiary Institutions in Nigeria: An Analytical Study. Malaysian Online Journal of Education. 2 (1) 20-36

[15]. Okolie, U. C., Elom, E. N. Ituma, A., Opara, P. N., Ukwa, N. J. Inyiagu, E. E. and Ndem, J. U. (2014). Roles of Entrepreneurship Education in Attaining Business Development Awareness and Skills Acquisition in Nigeria. IOSR Journal of Research \& Method in Education (IOSR-JRME). 4, (3), PP 37-44.

[16]. Okonkwo, O. (2011). Occupational/Vocational Guidance. Enugu. Cheston Ltd

[17]. Owino, A. (2005). An inquiry into the existence, establishment and service delivery of Guidance and Counselling units in secondary schools in Uasin Gishu District, Kenya. Unpublished M.Phil. Thesis, Moi University, Eldoret, Kenya.

[18]. Yuen, M. (2006). School counselling in Hong Kong: History, policy, current implementation status, and future directions. In C. H. So (Ed.), School counselling and career guidance. Macau. Pp. 44-70.

[19]. Yuen, M. (2002). Exploring Hong Kong Chinese guidance teachers' positive beliefs: A focus group study. International Journal for the Advancement of Counselling. 24(3), 169-182.

[20]. Whiston, S. C. (2003). Outcomes research on school counselling services. In Erford, B. T. (Ed.) (2003), Transforming the School Counselling Profession (435447). Upper Saddle River, NJ: Merrill Prentice Hall. 